\title{
PROCESSED PRODUCT DIVERSIVATION BASED COTTLE FISH FOR COASTAL FISHING COMMUNITIES
}

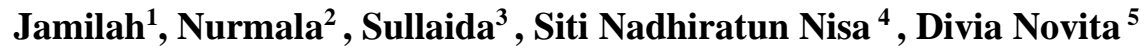 \\ ${ }^{1}$ Faculty of Agriculture Universitas Malikussaleh \\ ${ }^{2,3}$ Faculty of Economy Universitas Malikussaleh \\ ${ }^{4}$ Agribusiness student of Degree Program, Faculty of Agriculture Universitas Malikussaleh \\ ${ }^{5}$ Agribusiness student of Master's Program, Faculty of Agriculture Universitas Malikussaleh \\ Corresponding Author : jamilah@unimal.ac.id
}

\begin{abstract}
Correspondence Address : Jl. Cot Teuku Nie, Reulet, Muara Batu Sub Distric, North Aceh District Tel/Fax (0645) 41373

E-mail: 'jamilah@unimal.ac.id, 2)nurmala@unimal.ac.id, ${ }^{3}$ sullaida@unimal.ac.id
\end{abstract}

\begin{abstract}
The highest production (catching) of tuna reached $32.22 \%$ per year but the selling price of fish was very low, while the fish processing business was only in the form of wooden fish (keumamah) and smoking due to low mastery of technology and absorption of innovation. The business of processing tuna into shredded fish and fish crackers has never been carried out by the coastal fishing communities of Aceh, even though this business has the potential to be developed on a household scale. The service activity aims to provide training on processing tuna into shredded fish and fish crackers for fishing communities in coastal areas in the category of poor families. The method used is the survey method and Focus Group Discussion (FGD). Demonstrations of processing tuna into shredded fish and fish crackers can open up insights and business opportunities for housewives and young fishermen in creating added value and profit for traditional fishing households as well as improving production management and marketing of competitively processed fish. This activity can foster an entrepreneurial spirit among coastal fishing communities to increase fishermen's household income.
\end{abstract}

Keywords: Food diversification, tuna fish, shredded fish, fish crackers, coastal fishermen.

\section{INTRODUCTION}

Lhokseumawe City has a water area of $1,683.5 \mathrm{~km} 2$, with a coastal area of 2,236 km2 and a land area of $181.06 \mathrm{~km} 2$. The sub-district which has the smallest area in Lhokseumawe City, namely Banda Sakti $\left(11.24 \mathrm{Km}^{2}\right)$ is the most densely populated area with a density of 7,536 people per km2 spread over 18 villages, of which 9 are in the coastal area. The number of fishermen is 1,731 people, consisting of 1,251 permanent fishermen, 270 main part-time fishermen and 210 additional part-time fishermen. The amount of fish production in Lhokseumawe City for capture fisheries reaches 9,725.5 tons with the most fish production being tuna, which is 3,133.8 tons, while aquaculture is 3,337.02 tons. Thus, the total fish production per year is 13,062.52 tons (Lhokseumawe City Fisheries and Marine Service, 2020).

The number of fishermen in Lhokseumawe City in 2020 was 1,375 people and the largest number of fishermen was in Banda Sakti District, which was 1,060 people or 77.1 percent of the total fishermen. The old Javanese village is a coastal area in Banda Sakti District, which is $2 \mathrm{~km}$ from the capital Lhokseumawe. The total population is 8,699 people with a density of 14,498 and 2,009 households (Banda Sakti District in figures, 2020). Along the coastal area are slum housing (Figure 1) and most of the people work as fishermen. 


\section{Volume 2 No 1}

Processed Product Diversivation Based Cottle Fish for Coastal Fishing Communities DOI: 10.54443/irpitage.v2i1.59

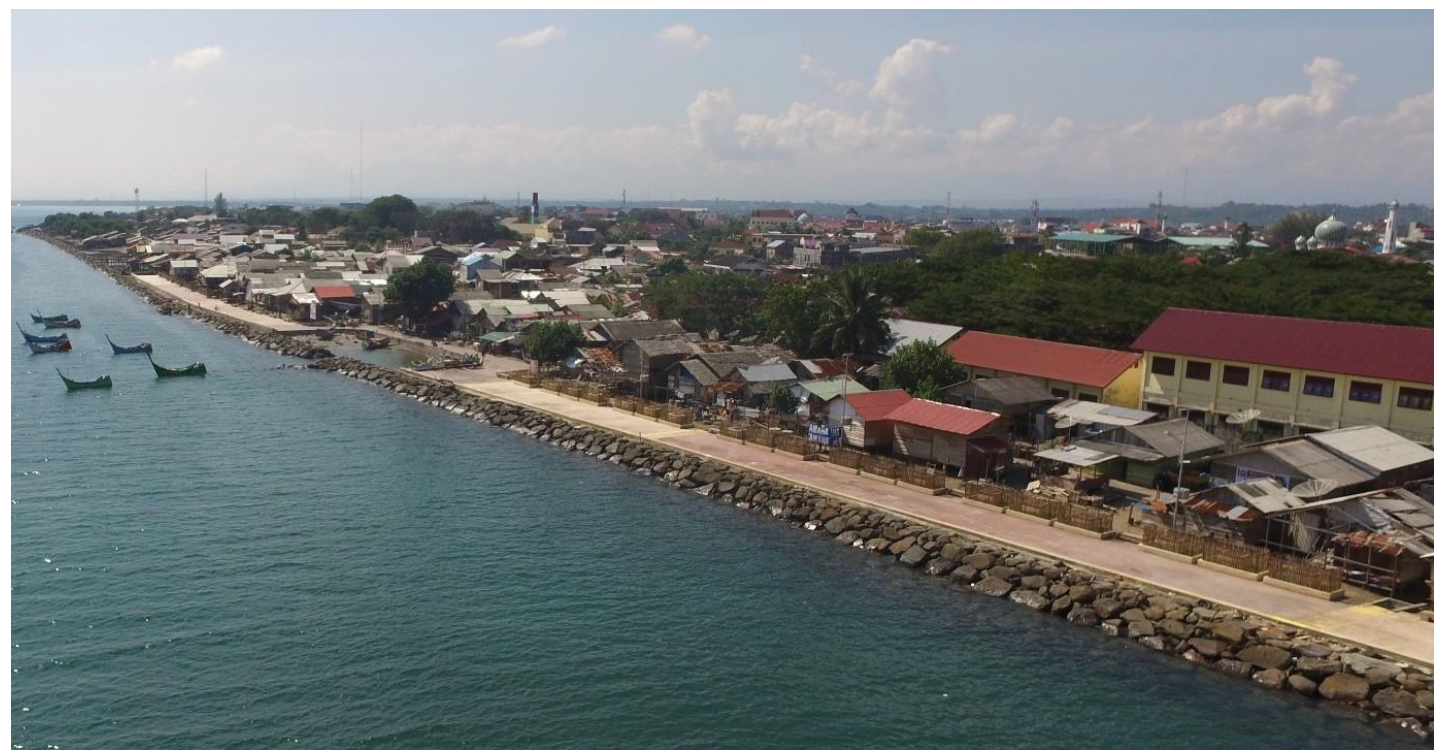

Figure 1.1: Slum Settlement in the Kampung Jawa Lama, Lhokseumawe City Source: Department of Human Settlements, Lhokseumawe City.

Most of the fishermen work as small fishermen, fishing laborers, small-scale fish processors and small traders because they have limited investment capabilities. Small fishermen are only able to utilize resources in coastal areas with catches that continue to decline due to competition with large ships and the decline in the quality of coastal resources. Perishable catch (fish) can weaken their bargaining position in sales transactions (Jamilah and Mawardati, 2018). In addition, the pattern of exploitative relationships between capital owners and laborers and fishermen, as well as seasonal and erratic fishing businesses make it difficult for poor communities in coastal areas to get out of the trap of poverty and debt with ship owners (Dahuri 2002, Adam 2012). Various regulations, qanuns, and other regulations that regulate the environment, including the coast, have not run as they should.

The average production of tuna is around 3,133.8 tons/year. Under normal conditions, the price of tuna ranges from Rp. $20,000 / \mathrm{kg}$ up to Rp. $25,000 / \mathrm{kg}$, but when production is high, the price of tuna is only around Rp. 5,000/kg up to Rp. 10,000/kg. At this price level there are traders who throw tuna up to $400 \mathrm{~kg}$ because it has rotted. The processing of tuna is generally carried out when fish production is high, in the form of keumamah fish, but in other coastal areas this fish is processed through smoking. Processing activities in Kampung Jawa Lama have not been carried out commercially, even though this fish can be processed into shredded fish, fish crackers, fish balls, smoked fish, with a home industry scale (agro-industry). On the other hand, the location of Kampung Jawa Lama is geographically only $2 \mathrm{~km}$ from the capital Lhokseumawe, and is a strategic cross-border as a distribution and marketing channel in North Aceh District, East Aceh District, and Bener Meriah District. The problems of the Coastal Fishing Community in Kampung Jawa Lama, Banda Sakti District, Lhokseumawe City are as follows:

1. Uncertainty in the income of fishermen,

2. weak access to capital

3. Low knowledge of fishermen's resources

\section{IMPLEMENTATION METHOD}

Training and mentoring activities for tuna fish processing business will be carried out gradually and systematically as a solution to solve a series of problems faced by coastal fishing communities in Kampung Jawa Lama, as follows: 


\section{$\hat{\vartheta}_{\text {RPITAGE }}$}

InTERnational REVIEW of PRACTICAL InNOVATION, TECHNOLOGy AND GREEN ENERgy

a. Establishment of a network of cooperation with fishing groups, in order to obtain a guarantee of raw materials (tuna) according to the quality and capacity of the agro-industry.

b. Production management training, namely the manufacture of shredded fish and fish crackers

c. Processed fish packaging management training

d. Product marketing management training

e. Business development assistance.

Location Service activities are carried out in Kampung Jawa Lama, Banda Sakti District, Lhokseumawe City, with consideration as a coastal area that has the largest number of traditional fishermen, high tuna fish production potential, with a fairly high population and belongs to slum settlements in Lhokseumawe City, but geographically has a strategic cross-section in the distribution and marketing of processed products

\section{RESULTS AND DISCUSSION}

\subsection{Activity Implementation}

In 2021, the total production of fish from capture fisheries in Lhokseumawe City is $9,785,582 \mathrm{~kg} /$ year, with the highest fish production respectively being tuna with $3,133,789 \mathrm{~kg} /$ year, anchovy as much as $564,420 \mathrm{~kg} /$ year, side fish as much as $292,980 \mathrm{~kg} /$ year, mackerel as much as 245,014 kg/year, and jackfruit seed fish as much as 81,582 kg/year (BPS Kota Lhokseumawe, 2021).

Work as a fisherman who works at sea is a job full of risk and is strongly influenced by natural factors, so that the income obtained from fishing is uncertain throughout the year which is based on the season and the price of fish. During the harvest season, the income obtained by fishermen can be said to be adequate to meet their daily needs, but during the lean season or the rainy season with high storm intensity, their income level can be said to be low and sometimes the fishermen do not earn any income. at all because fishermen do not go to sea for reasons of safety. Despite their uncertain income, the most prioritized consumption is to meet their basic needs such as consumption for food.

Fishermen's income is generally determined by profit sharing, so there is rarely a system of salary or fixed wages received by fishermen. In this profit-sharing system, the income for fishermen is income after deducting exploitation costs that have been incurred during operation plus the cost of selling the results. This profit-sharing system often tends to be less profitable for fishermen, especially labor fishermen (Mulyadi, 2007). Abundant fish production in certain wind seasons has an impact on the decline in fish prices, especially the price of tuna, which reaches Rp. $5,000 / \mathrm{kg}$. This condition is very detrimental to fishermen and causes fishermen to be unable to meet their household needs and makes it difficult for them to get out of poverty. On the other hand, the low education level of fishermen (the average is at the elementary level) and some have never attended school and the lack of mastery of skills means that they do not have the opportunity to get a decent job. In this condition, special action is needed through empowering fishermen with assistance so that they can carry out fish processing activities that can be carried out on a household scale and have high economic value to foster an entrepreneurial spirit in an effort to increase the income and welfare of coastal fishing communities.

Uncertainty in obtaining fishermen's income, weak access to capital and low limitations of fishermen's resources will cause the ability of fishermen's households to meet their food needs is very dependent on the economic capacity of their households (Jamilah, 2015). On the other hand, the potential for high capture fisheries, especially tuna production, is only sold in the form of fresh fish. The processing of tuna into keumamah fish is only done on a small scale and is noncommercial. Tuna-based agro-industry is feasible to develop considering the high potential of fish, easy to implement and can be done on a home industrial scale. Until now, there is no business of 
processing tuna into shredded fish and fish crackers in Lhokseumawe City and North Aceh Regency.

Training activities to make tuna into shredded fish and fish crackers are very important, given the high consumer demand for ready-to-eat processed fish. These activities include training in the manufacture of processed fish, business coaching and mentoring including production management and marketing. Based on an agreement with the village administrator, this activity is intended for fishermen's wives and young women, and is carried out gradually and continuously so that a tuna fish processing business group will be formed.

The tuna-based agroindustry will serve as a forum for collaboration between the Agribusiness Study Program, Faculty of Agriculture and the Management Study Program, Faculty of Economics and Business, Malikusasleh University as supervisors and assistance with coastal fishing communities in Kampung Jawa Lama as implementers and village officials as administrators and directors. The mentoring activity for tuna processing business will involve students of the agribusiness study program as a village development activity.

The training on processing tuna into fish crackers and shredded fish was conducted to inspire respondents to the importance of healthy fish processing business that can be done on a household scale and to increase household income. The results of the observations showed that young women were very enthusiastic about participating in this activity, and they were fostered to be able to do it on a joint group business scale.

The processing activities of fish crackers and shredded fish are focused on product development, increasing cooperation, seizing opportunities to increase income, and economic empowerment of coastal communities in Kampung Jawa Lama Village, Lhokseumawe City.

1. Fish cracker products, and shredded fish with the taste of tuna. In the future, innovation is needed in the form of balado and corn flavors to arouse consumer tastes. Generally, people want fish crackers that are crispy and not musty.

2. Packaging uses thick plastic to prevent the crackers from becoming soft (soft) so that they can maintain the quality of the crackers. Packaging is done to limit or reduce the contamination of food from the surrounding environment, as well as to function in delaying the occurrence of quality degradation or damage.

3. Marketing of fish crackers and shredded fish can be done through retail, especially in the marine tourism area of Ujung Blang. The results of the observations show that there is a high demand for crackers in tourist areas. This is an opportunity for coastal communities to develop fish crackers and shredded tuna by promoting innovation in form and taste.

4. Processing of fish crackers and shredded fish can be done independently or in groups, considering the relatively minimal capital and very easy to do. This activity can empower young women and housewives to take advantage of business opportunities that can increase creativity and household income.

\subsection{Program Constraints}

Changes in the mindset of coastal fishermen who always feel in a safe and comfortable position so that they are not motivated to change lifestyles and economic activities that can increase income and welfare of life, are not easy to do. This is due to low education and difficulty accepting business innovations that have economic value. In its implementation, several obstacles were found, including:

1. Difficult access to capital. Until now there is no financial institution that provides facilities for fishermen to get business credit and the lack of assistance for coastal communities. This makes fishermen tied to the owners of capital (toukebangku).

2. The production of tuna is seasonal. In this case, it is directed to utilize other types of fish such as anchovies, tuna, dencis, and other types of fish and shrimp. 


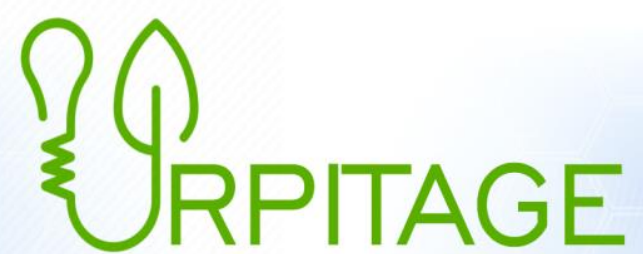

InTERnational REVIEW of PRACTICAL InNOVATION, TECHNOLOGy AND GREEN ENERgy

https://radjapublika.com/index.php/IRPITAGE/

3. There is no fish-based culinary tourism in Aceh Province, so fish-based products are not yet commercial and not widely known by the Acehnese people.

4. The lack of empowerment programs for coastal communities, both in the scale of skill improvement and the development of commercial businesses.

5. The lack of promotion for Aceh's superior products so that marketing is only in the Aceh Province area.

6. The lack of use of technology both in the fishing business, fish processing, and product marketing.

7. There is no company-scale fish processing business in Aceh Province, which has high implications for the decline in fish selling prices when fish catch (production) is high by fishermen. This is because the demand for fresh fish is limited to the household level, not at the agro-industry level.

8. There is no standardization of processed products to ensure product quality, resulting in a lack of demand for fish-based processed products outside the province of Aceh.

\subsection{Business Development Prospect}

Kampung Jawa Lama Village has a very strategic position because it is located in coastal waters, close to Ujung Blang marine tourism, and is in the center of Lhokseumawe City so that it is easily accessible by consumers. The economic activity of the community is fishing and trading, making it easier to market products. The local government can make this village an icon of a culinary tourism village for processed fish-based products.

This training was closed with a photo session with the service team with the training participants.

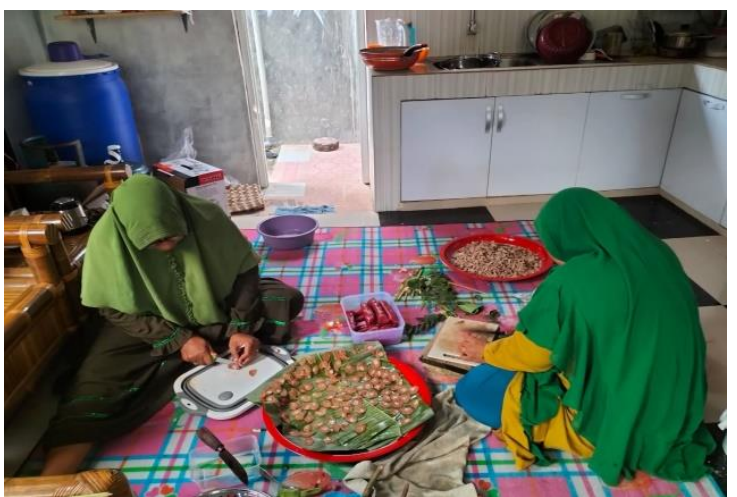

Production of shredded fish and fish crackers

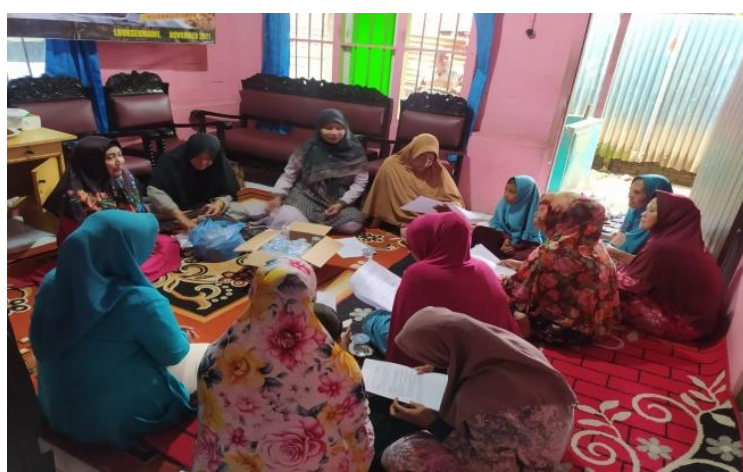

Marketing Management

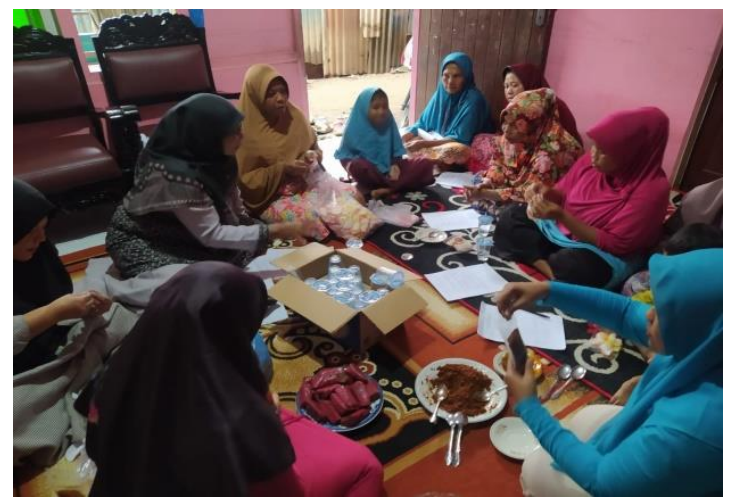

Packaging of shredded fish and fish crackers

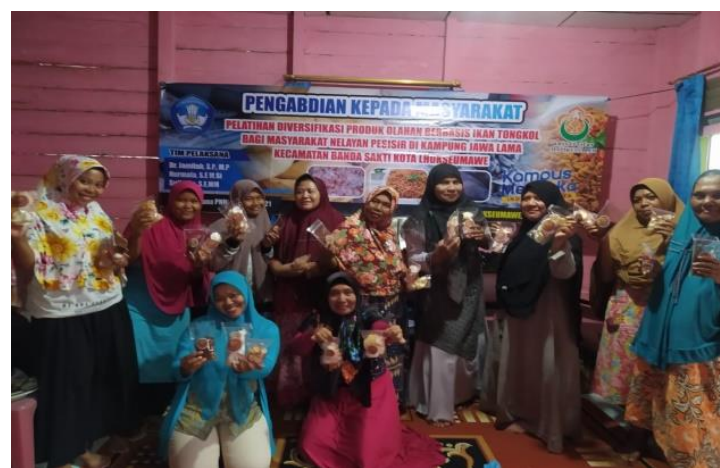

Products ready to be marketed

Figure 2. Group photo with trainees 


\section{CONCLUSION}

a. The activity of processing tuna into shredded fish and fish crackers has achieved the target and coastal fishing communities have understood the importance of utilizing marine fishery resources to increase household income.

b. This activity is carried out in the form of technical training and marketing management so that coastal fishing communities can develop processed fish-based products by promoting digital technology innovation.

c. There is a change in community interest to create profitable business opportunities based on local fishery resources.

\section{Acnowledgment:}

This service can run well with the support of village administrators and coastal fishing communities as well as funding assistance from Non-Tax State Revenue (PNBP) in the Malikussaleh University Budget Implementation List (DIPA) for Fiscal Year 2021 through the 2021 Fostered Village Service Grant Scheme and facilitated by LPPM Malikussaleh university

\section{REFERENCES}

Adam, L. (2012). Sustainable Fisheries Development Policy (Case Study: Wakatobi Regency, North Sulawesi Province and Morotai Island Regency, North Maluku Province). Journal of Fisheries and Marine Affairs. 2(2): 115-126.

BPS Lhokseumawe City. (2020). Banda Sakti District in numbers. 2020. BPS Lhokseumawe City. BPS Lhokseumawe City. (2021). Lhokseumawe City in 2021 figures. BPS Lhokseumawe City.

Dahuri, R. (2002). Indonesian Coastal Zone Management Strategy. PKSPL. Bogor Agricultural Institute. Bogor.

North Aceh District Marine and Fisheries Service. (2020). Annual Report. North Aceh District Marine and Fisheries Service.

Jamilah. (2015). Analysis of Income Uncertainty for Aceh Fishermen. E-Mabis Journal. 16(1): 37 46.

Jamilah, Mawardati. (2018). The Minapolitan Program and Its Role in the Development of Capture Fisheries in East Aceh District. Journal of Management Applications. 16(1): 162-170.

Mulyadi S. (2007). Marine Economics. Jakarta: PT. King Grafindo Persada. 